\title{
Research on Bank Relationship and Its Impact on Capital Structure: A Study of Listed Companies on Kse Pakistan
}

\author{
Jahanzaib Sultan, Fahad Javed, Qing Yang \\ School of Management, Wuhan University of Technology, Wuhan, 430070, China, \\ E-mail: jzsultan@hotmail.com, mfahadjaved@gmail.com, yangq@whut.edu.cn
}

\begin{abstract}
Business firms are meant for profitability, growth and wealth maximization. In order to improve and investigate the factors which are influencing a firm performance are extensively studied by many researchers. Banking being the major source of financing to such firms is being targeted by researcher in the said perspective. A new idea has been discussed in this research by including banking relationship as a determinant of capital structure of the firm. This research has obtained the data for $\mathbf{1 8 0}$ listed firms for a period of 2008-2013 and investigates the impact of bankfirm relationship on the debt to equity ratio of the firm. The result shows that the dependent variable is significantly influenced by number of banking relationship a firm is maintaining. The dummy used for multiple bank relationship is however insignificant in order to explain the variations in capital structure of the firm. In the lights of the results it can be said that the optimal number of banking relationship is needed to maintain a particular capital structure ratio and ultimately the performance as the interest rates in developing countries such as Pakistan are quite higher than those of developed ones.
\end{abstract}

Keywords-Multi-bank relationship (MBR); Capital structure; Bank relation; Debt to equity

\section{INTRODUCTION}

Banking industry of any country is quite important for its growth and development of its economy. Therefore, a huge number of studies have been done in this regard [1]. Barth Barth, et al. [2] explains that the research on banking relationship in emerging markets as the market characteristics are very different from those of developed countries. Bank-firm relationship remains an issue of interest for the researcher. Levine [3] posits that banks are a helping hand of economy but at the same time they are also pursuing their own growth and profitability [4]. This conflict of opinion raises a question about the loyalty of this relationship between firms and banks.

Although as a research interest bank relationship is not a new topic yet a very few attempt is made regarding developing markets (A.N. Berger et al., 2008) like China, India and Pakistan but as per authors knowledge it is the first attempt to investigate this relationship in context of Pakistan.
This research is focused to investigate the impact of firm bank-firm relationship on the health of relationship firm and its performance and is based on the traditional theory of capital structure which says the choice of optimal capital structure is important for a better performance. We will try to link the results posits by [5] to our idea of research by concluding the impact of bank relationship on capital structure of the firm and ultimately affecting its performance.

In the next session we will discuss the literature on banking relationship, multiple relationship and determinants of capital structure. Remainder part will discuss the banking sector of Pakistan then the data and methodology will be presented. In the end we will discuss the results and conclude with some suggestion for future research in Pakistan context in this regard.

\section{LITERATURE REVIEW}

The most common type of bank-firm relationship is credit relationship as bank provides the capital alternatives for the firms. So, the firm performance can be affected in both ways due to change in cost of capital. Researchers mostly support that bank through better monitoring contributes in firm's performance [6, 7]. Angelini, et al. [8] reports that if the number of bank relationships increased the interest rate charged by creditor banks will decrease which leads to reduction in total cost of capital and better performance of the firms in such relationships. In a research for Japan Weinstein and Yafeh [9] posit the same in a different way as the main and exclusive bank relation results in high interest payments than other banks.

Contrary to the above researches, the multiple banking relationships even increase the interest rates [10] and in some cases ( Belgian firms) when a firm borrows from a second bank pays higher interest rates than its first bank [11], and may lack the credit availability [12], which is in favor of the theory that single bank relationship is more beneficial for the firm's profitability. However, some researchers report no effect on contract terms [13, 14].

According the theory of capital structure, an optimal choice of capital structure plays a key role to determine the firm performance through low weighted average cost of capital especially in the developing countries where the cost of debt and financing is relatively higher than those of European countries. Many researchers have tried to explore and investigate the relationship between capital structure and firm performance and the present literature can be 
segregated in three dimensions i.e. positive, negative and neutral.

Akintoye [15] confirmed that any change in the level of debt or equity will modify the firm's value. In a study conducted by Pathak (2011) as cited by Salim and Yadav [16] posits significant but negative relationship between level of debt and firm performance which is consistent with the result of studies done for Asian countries where the cost of borrowing is higher than the western countries. Some other researchers argued the same by presenting their results for negative relation between long term debt or leverage and performance [17-19].

In the bank based economies, where the main source of financing remains the banks, the banks may also grab the economy by pursuing profit maximization and rent seeking behavior [4, 20]. In the said scenario the bank-firm relationship becomes harmful for the related firm as the contract terms like interest rate and collateral requirements becomes more adverse [21]. Following its own interest of profit maximization a bank may influence the related firm to modify the capital structure without a practical need. This logic has been argued by Yao and Ouyang [5] while doing research on Japan. Their results show that the Main Bank Power is positively related to the level of loan of the relationship firm and the interest expense to total asset ratio was also high.

\section{METHODOLOGY}

In the following section we will try to explain our data source, sample and control variables. Then, we will design our regression model.

\section{A. Data source}

As most of the researches focuses on developed markets, for this research we have taken Pakistan as our area of interest being the emerging market and developing country. Total number of listed firms on Karachi stock exchange (KSE) are 581. 75 firms are from financial and equity investment sector. This reduced the number of firms to 506 in which 24 listed firms are commercial banks. 32 firms are from insurance sector which reduced our sample of interest to 450 listed companies. We have taken data of 180 nonfinancial firms (for which data is available) listed on Karachi stock exchange (KSE) from 2008 to 2013 and total number of observations is 1056 .

The data of the listed companies in Karachi Stock exchange is obtained from their published financial reports.
We have gathered a data from the official websites of the listed companies for a period from 2008-2013.

\section{B. Variables \\ NBR and MBR}

In order to check the impact of bank-relation we have taken different type of proxy variables. Number of bank relations (NBR) is taken as the measure for actual number of banking relations exist for a single firm. Secondly, a dummy variable (MBR) is used for the multiple bank relations existence which will attain a value of 1 if the firm is maintaining more than 5 relations. This definition of the variables is consistent with Berger, et al. [1].

In order to build our next model we have referred to the methodology of [5], their research was aimed to check the impact of number of bank relationships on the loan to debt ratio of the firm. We extend this model to investigate number of bank relationships in terms of capital structure of the firm. For the said cause we have used other determinants of the capital structure (MV/BV, FSIZE, FAGE, TANG, LIQ) as control variables for our study. Our regression model is as follow:

$$
\begin{gathered}
\frac{D E B T}{E Q U I T Y}=\alpha+\beta 1 M B R+\beta 2 M B R+\beta 3 \frac{M V}{B V}+ \\
\beta 4 F S I Z E+\beta 5 F A G E+\beta 6 T A N G+\beta 7 L I Q+\varepsilon .
\end{gathered}
$$

\section{DESCRIPTIVE STATISTICS}

The debt to equity ratio for the study period ranges from -0.071 to 0.296 with an average value of 0.002 . This ratio depicts that some firms have reported negative equity due to heavy losses during the observed period. Descriptive statistics shows that on average the firms are maintaining 9 banking relationships while the maximum value of number of bank relationships are 29. Liquidity of the firms remains an issue for the said period with the maximum value of 0.67 and an average of -0.006 which shows the firms are less liquid. Tangibility attains a maximum value of 2.52 with an average of 0.55 which implies that the firms are maintaining $50 \%$ of tangible assets. The firms in the sample are old enough as the mean value is 32 with a maximum of 127 years. We have taken Ln of the assets in order to determine the size of the firms and normalize the data which has a mean value of 21.98 and a maximum value of 26 .

The correlation analysis of the independent show that there is no multicollinearity among our selected variables as the max value is not higher than 0.8 . 
TABLE 1: REGRESSION ANALYSIS

\begin{tabular}{l|c|c|c|}
\hline Variable & Expected Sign & Coefficient & P>t \\
\hline NBR & + & 0.00023 & 0.0007 \\
MBR & + & -0.0001 & 0.1166 \\
SIZE & + & -0.00046 & 0.0561 \\
AGE & + & -0.00028 & 0.0251 \\
\cline { 2 - 4 } TANGIBILITY & - & -0.003 & 0.0000 \\
LIQUIDITY & - & -0.0044 & 0.0000 \\
\hline
\end{tabular}

NBR is the number of bank relationships. MBR is a dummy variable for multiple bank relationships which attains value of 1 (if number of bank relationships is >5). SIZE is natural log of assets. TANGIBILITY is the ratio of net fixed assets and inventory to total assets. LIQUIDITY is working capital to total assets.

The regression results of our model are shown in Table1. The regression analysis for debt to equity or capital structure of the firm is done by OLS method with robust standard errors. The figures shown in above table assures that the number of bank relationship (NBR) has a significant (at $1 \%$ ) and positive impact on the capital structure of the firm which is same as expected which means that $\mathrm{H} 1$ is accepted. The dummy for multiple bank relationship has not shown significant results. SIZE, AGE, TANGIBILITY and LIQUIDITY results are also significant for the study but the impact of SIZE and AGE is negative.

\section{Discussion and Conclusion}

This paper aims to explain the contribution of number of bank-firm relationship in the decision of capital structure of firm in Pakistan. We have taken the number of bank relationships a listed firm is maintaining in Pakistan and how this relationship is affecting or influencing the choice of capital structure. The result assures that the number of bank-firm relationships has positive and significant impact on the debt to equity ratio of firm. This implies that if the number of bank relationships increases the capital structure will be relying more on the debt. While the other dummy variable (MBR) has not shown some significant impact on this ratio.

Banks remains the biggest source of funding for the firms but it is needed to investigate the actual impact of these numbers of relationship on the health of firm. The firms are establishing bank relationships in order to get financing for their future investments and meeting the current needs. On average the firms in our study maintains 9 banking relationship which is contrary to the developed countries. These results derive the attention towards the number of bank relationship a firm should maintain in order to optimize the capital structure of the firm.

Future research can be done on banking relationships and firm performance by including the interest payments and its ratio to the debt to investigate this issue further.

\section{REFERENCES}

[1] A. N. Berger, L. F. Klapper, M. S. M. Peria, and R. Zaidi, "Bank ownership type and banking relationships," Journal of Financial Intermediation, vol. 17, pp. 37-62, 2008.

[2] J. R. Barth, G. Caprio, and R. Levine, Rethinking bank regulation: Till angels govern, Cambridge University Press, 2005.
[3] R. Levine, "Financial development and economic growth: views and agenda," Journal of economic literature, vol. 35, pp. 688-726, 1997.

[4] R. G. Rajan and L. Zingales, "The great reversals: the politics of financial development in the twentieth century," Journal of financial economics, vol. 69, pp. 5-50, 2003.

[5] J. Yao and H. Ouyang, "Dark-side evidence on bank-firm relationship in Japan," Japan and the World Economy, vol. 19, pp. 198-213, 2007.

[6] J. K. Kang, A. Shivdasani, and T. Yamada, "The effect of bank relations on investment decisions: An investigation of Japanese takeover bids," The Journal of Finance, vol. 55, pp. 2197-2218, 2000

[7] R. S. Kroszner and P. E. Strahan, "Bankers on boards:: monitoring, conflicts of interest, and lender liability," Journal of Financial Economics, vol. 62, pp. 415-452, 2001.

[8] P. Angelini, R. Di Salvo, and G. Ferri, "Availability and cost of credit for small businesses: customer relationships and credit cooperatives," Journal of Banking \& Finance, vol. 22, pp. 925-954, 1998.

[9] D. E. Weinstein and Y. Yafeh, "On the costs of a bank-centered financial system: Evidence from the changing main bank relations in Japan," The journal of Finance, vol. 53, pp. 635-672, 1998.

[10] M. A. Petersen and R. G. Rajan, "The benefits of lending relationships: Evidence from small business data," The journal of finance, vol. 49, pp. 3-37, 1994.

[11] H. Degryse and P. Van Cayseele, "Relationship lending within a bank-based system: Evidence from European small business data," Journal of financial Intermediation, vol. 9, pp. 90-109, 2000.

[12] S. E. Black and P. E. Strahan, "Entrepreneurship and bank credit availability," The Journal of Finance, vol. 57, pp. 2807-2833, 2002.

[13] A. Machauer and M. Weber, "Number of bank relationships: An indicator of competition, borrower quality, or just size?," CFS Working Paper2000.

[14] D. Harhoff and T. Körting, "Lending relationships in GermanyEmpirical evidence from survey data," Journal of Banking \& Finance, vol. 22, pp. 1317-1353, 1998.

[15] I. R. Akintoye, "Sensitivity of Performance to Capital Structure," Banking and Finance Letters, vol. 1, p. 29, 2009.

[16] M. Salim and R. Yadav, "Capital structure and firm performance: Evidence from Malaysian listed companies," Procedia-Social and Behavioral Sciences, vol. 65, pp. 156-166, 2012.

[17] I. Chakraborty, "Capital structure in an emerging stock market: The case of India," Research in International Business and Finance, vol. 24, pp. 295-314, 2010.

[18] G. Huang, "The determinants of capital structure: Evidence from China," China Economic Review, vol. 17, pp. 14-36, 2006.

[19] J. Abor, "The effect of capital structure on profitability: an empirical analysis of listed firms in Ghana," The journal of risk finance, vol. 6, pp. 438-445, 2005.

[20] Z. Chen, Y. Li, and J. Zhang, "The Bank-firm Relationship: Helping or Grabbing?," International Review of Economics \& Finance, 2015. 
[21] S. A. Sharpe, "Asymmetric information, bank lending, and implicit contracts: A stylized model of customer relationships," The journal of finance, vol. 45, pp. 1069-1087, 1990. 